Vladimir Mitrovic, $\mathrm{MSc}^{1}$

Ivana Mitrovic, $\mathrm{MSc}^{2}$

University of Priština, Faculty of Economy
SCIENTIFIC REVIEW ARTICLE doi:10.5937/ekonomika1502169M

Received: January 24, 2015

Accepted: March 26, 2015

\title{
CLUSTER DEVELOPMENT AND IMPROVEMENT OF THE COMPETITIVENESS OF THE ECONOMY IN SERBIA
}

\begin{abstract}
While in developed countries is growing interest in clusters, they are still in Serbia have not attracted enough attention to policy makers, so even businessmen. In this sense, the task of our government is to create a favorable economic environment in which clusters emerge and develop. To accomplish this task, it is necessary to use the experience (recommendations and measures) that are developed at EU level, but also examples from countries that have managed to seize the concept of clusters in order to improve competitiveness to national economy. For our SME association is a precondition for their effective involvement in the supply chains of large systems and increase their business and export performance.
\end{abstract}

Keywords: cluster development, competitiveness, cluster policy, Regional policy development, innovative SMEs

JEL Classification: R11 L22 L26

\section{РАЗВОЈ КЛАСТЕРА И УНАПРЕЪЕЊЕ КОНКУРЕНТНОСТИ ПРИВРЕДЕ У СРБИЈИ}

\begin{abstract}
Апстракт
Иако код развијених земаља расте интересовање за кластере, они још увек у Србији нису привукли у довољној мери пажюу како креатора политика, тако ни привредника. У том смислу, задатак наше Владе је да створи повољан привредни амбијент у коме ће кластери настајати и развијати се. За остварење тог задатка, потребно је користити искуства (препоруке и мере) које су развијене на нивоу ЕУ, али и примере из праксе земаља које су успеле да искористе концепт кластера како би унапредиле конкурентност националне привреде. За наша МСПП удруживање је предуслов њиховог ефективнијег укључивања у ланце снабдевања великих система и повећање нихових пословних и извозних перформанси.
\end{abstract}

Кључне речи: развој кластера, конкурентност, политика кластера, регионална политика развоја, иновативност МСПП

\footnotetext{
1 vladam@gmail.com

2 same address
} 


\section{Introduction}

The impact of the global environment necessitates focusing firms to create competitive and innovative products and services. Companies can raise their benefits through a variety of business activities, the most accelerating product innovation and increasing productivity. However, experience has shown that there is no limit to the diversification and, if it is not closely related to sustainable competitive advantage at the level of the business units, often destroying economic value. One way of raising the efficiency and effectiveness of business development companies (companies), and therefore their competitiveness is through joining the cluster. Firms can achieve much more by working together as a group of interconnected companies, suppliers, service providers and organizations relevant to their business within the cluster. Stimulate networking firms in clusters proved in practice to be effective concept or instruments for strengthening the competitiveness of companies and their training to produce goods and services of a higher level of processing that will be sold in the domestic and global markets.

To be competitive, companies need to identify competitive advantages that the cluster may have, and to know how these benefits can be increased or expanded. As for the success of the cluster is not enough to simply associating entities, neither company by joining the cluster will provide better performance and higher profits, but success will depend on whether you have created value and innovative potential. A successful cluster can create the necessary basis for cooperation between firms and specialization, promote private-public dialogue, to encourage external stakeholder and accelerate innovation.

This article is the result of the work of the authors, using data of primary research in reference domestic and foreign institutions, data and information from interviews with a number of managers of clusters, cluster members and / or representatives of institutions involved in the implementation of cluster initiatives, as well as secondary data and results of domestic and foreign authors in this field, whose aim was to show how to improve the competitiveness of the national economy through the development of clusters. Question popularization of clusters is particularly important in current Serbian economy, in which the policymakers are increasingly prominent focused on finding the leading multinational corporations, whose entry into the domestic market and the start of production, with the possibility of its investments around the world, to create conditions for download part of their supplier functions of the domestic segment of small and medium enterprises and entrepreneurs (hereinafter referred to as SMEs).

\section{Cluster connection as a premise for strengthening the competitiveness of enterprises}

Harvard professor Michael Porter, first introduced the concept of clusters (clusters) in the economic literature in 1990 and defines them as "geographically close group of companies and associated institutions in a particular field of industrial / branch, connected to the common benefit and complementary" (Porter, 2008, p. 6).

The advantages of clusters to strengthen competitiveness are numerous, and one of the main consists in the fact that clusters enable economies of scale, as they are usually formed within specific industries, like the value chain, similar to the structure and often follow a similar strategy. Clusters are the result of voluntary association, and for the survival and development of the cluster there are national and regional barriers. Also, the benefits of association of enterprises in clusters reflected through easier access to 
the latest knowledge, stimulate the exchange of knowledge, provides the cost savings, creates the possibility of cooperation, support to innovation and encourage competition, and creates the critical mass necessary for further growth (Andreozzi, 2005 , p. 2).

The success of enterprises and economic development of enterprises in the cluster is not limited to these companies, their employees and associated sectors. Progress and production activities in the cluster have a synergistic effect on the entire community, as well as the macro-economy. The successful development of clusters and creates structural changes, both at local and at the macro level. The development of industrial activities in the cluster encourages the development of the sector outside the cluster, as a result of the interaction of industrial relations that exist at the regional level.

Clusters arise primarily because of the necessity of survival of SMEs. Through its association, these companies simply " mimic " operation of large enterprises, while retaining legal and business independence. In that way, clusters become competitors or collaborators of large enterprises. In this way, SMEs were able to maintain their market position and achieve sustainable growth and business. The most common association in clusters of entrepreneurs and SME owners are in sustainable development and profit. Activities such as price agreement, transfer of technology, conquering new markets, buying licenses and others can not be successfully done by an entrepreneur or small business owner.

Clusters as the concentration of specialized institutions and companies linked through multiple contacts, enabling the creation of useful innovations. In the conditions of modern competition, the tendency is that the clusters are more innovative clusters. Empirical evidence supports the argument that the member companies of clusters of innovative companies that are not members of the cluster (The Gallup Organization, 2006, p.11-15). Also, empirical evidence suggests that there is a positive correlation between the strength and power of the cluster regions in innovation and development of new invention.

Specialization of enterprises is essential to the success of the cluster, where a small company focused its resources (which are usually extremely limited) on what they do best (Ketels et al, 2003, p.18). Specialized firms usually do not have problems with quality control, as do only one thing, but we have to work very well. Development of cluster is accompanied by an increase in specialized technical and marketing skills of local human resources. Local workers, technicians, managers and consultants often vary from company to company and thus the advantage of specialization belongs to the local system, not just one company. Moreover, local infrastructure and training institutions are becoming specialized in cluster activities.

One of the key factors for successful business clusters, the production of products which must be complied with all members of the cluster. Therefore, as the need arises standardization of the entire management system. Clusters by standardizing can more easily manage their production process.

Some clusters may initially have a weak competitive position and limited growth potential, but that does not mean they should be ignored in terms of further growth. Many small clusters provide highly specialized services in the global market and continue to develop further. Such a situation is, for example, in the software industry clusters. Many clusters of manufacturing experience this situation, for example, during the restructuring.

\section{Privacy and software development of clusters}

Although clusters are primarily the result of individual effort and private companies, one of the ways that successful clusters appear in the economy of a country or region is that there is an appropriate policy of cluster development. In this sense, there may 
be one comprehensive policy for clusters which give specific frames as they should be encouraged to monitor their development. In addition to the general framework, the clusters can set the framework for other policies. First of all, it is usually the case in three key areas: policy innovation and technological development, regional economic development policy and policy entrepreneurship / SME. But it can be manifested in many other policy areas. The European Commission, for example, stimulates the development of border clusters and the emergence and revival of strong European clusters through trans-European Cluster Policy participate in the support and development of clusters (Sölvell, 2008, p. 50-58).

Combining the efforts of the public sector and private and implementation of cluster policy are important elements of building strong innovation systems as a prerequisite of growth and job creation. Privacy clusters may be the way the economy of a country can build competitiveness and mobilize the necessary multi-year software support and commitment of all major carriers of the innovation process. Because of their complexity cluster policy can be categorized into three segments: The first segment is the microeconomic policies to create an attractive business environment for growth and innovation that directly encourage the development of clusters. The second segment includes SME policy, research and innovation policy and regional development policy. The third segment is developing policies aimed at creating, mobilizing and strengthening certain level of categories of clusters, and result of certain sector's cluster initiatives (OECD, 2007, p. 5-13).

The fact is that the vast majority of cluster develops without the help of a policy aimed at their conception and surprisingly often cluster participants do not meet each other, and the public authorities or insufficiently recognize the importance of the clusters for the local economy. However, these clusters make a positive contribution to the region where they are, and create growing pressure to create policies that can encourage creating conditions for the development and the revival and development of clusters or increase economic benefits from them.

The success and the level of development in the EU clusters largely depends on institutional support. Decision-economic policies are especially advocated a policy of cluster development due to a shift of focus from macro to micro-economic issues. In some EU countries, the development of regional clusters represents a new form of industrial policy, while in other countries such as Portugal, Denmark and the UK there is an initiative to create a map of clusters and cluster policy formulation. Otherwise, in all European countries, monetary and fiscal policies are generally well developed, but it turned out to be successful macroeconomic policies only prerequisite, but not a sufficient guarantee for faster development. Key developments in the microeconomic efforts aimed at new connections with the private sector, universities and other institutions also to enable it to effectively implement macroeconomic objectives.

No matter what the significance of cluster policy at the national level varies among EU countries, it is considered to have a high or medium priority in most countries. One gets the impression that the national cluster policy in some countries less important especially in countries that are organized as federations and / or where there is a high degree of regional autonomy (Sölvell, 2008, p 50-53). On the other hand, although the formation of clusters is crucial initiative "bottom up", in countries such as Serbia process of creating clusters is necessary to initiate, manage and financially encouraged.

Within the cluster policy is necessary to achieve a significant degree of integration of different types of measures, determining the duties and responsibilities of specific institutions and entities for the implementation of the policy, which requires strategic alignment and practical cooperation within the framework of state institutions. Cluster 
policy should be designed to support the emergence of new connections and growth (development and strengthening) of existing clusters (Anderson, et al, 2004, p. 5). In addition, it is necessary to cluster policy be flexible in order to adapt to the new requirements, many barriers and limitations.

Thus, government support as well as creating a climate of mutual trust in the cluster are necessary preconditions for their development. Efforts to develop a cluster must include the search for competitive advantage and specialization, and not attempt to blindly support what exists in other locations. Despite the risks associated with regional specialization, the clusters based regional economy generates better results.

\section{Selected European experience in creating clusters}

The fact is that in the transitional economy policy development is often based on a centralized approach, and where support when it comes to competitiveness, usually poorly supported. The event challenges is that on the one hand the company weak and lack the confidence and skills of cooperation, while on the other side of the country often lack the resources to do its job. Experience shows that this deficiency usually overrides donor funds to support policies launched cluster development. In the following, we will give experience and steps in the development of cluster policy of some countries that are now in post-transitional stage, and are members of the EU.

Slovenia is applied in designing the cluster approach "dynamic concentric circles", which enables the connection of small and medium-sized enterprises in clusters around leading companies. Slovenian automotive cluster includes formal Automotive Cluster of Slovenia (ACS), which was formed with the support of the Government of Slovenia in 2000 and a large number of companies and institutions specialized in the supply chain of the automotive industry that are members of the cluster tool manufacturer or Slovenian cluster of plastic, a smaller informal clusters, or are not members of either formal nor informal clusters. A total comes to more than 200 companies, mostly medium-sized, which are included in the automotive supply chain. Joint venture between Renault and Revoz is considered a key moment in the development of clusters. Thanks Revoz, which became an affiliate of Renault, Slovenia became an important trade partner of France. The essence of relationships in the cluster represents the vertical interactions in the supply chain between small and large local companies. Cluster membership is an opportunity for companies that combined can serve large orders, as in the independent appearance is not the case. Today the car and the associated clusters generated close to $15 \%$ of total exports of the country, where the third thanks to its Revoz (Borras, Tsagdis, 2008 , p. 150). Approximately $80 \%$ of the cluster is placed on the EU market (Boskovic Institute, 2011, p. 54-68), a cluster is also one of the largest generators of employment in Slovenia. By combining the concept of a cluster of companies in the supply chain of Slovenian automotive industry, created the conditions for strengthening their individual and collective capacity to develop partnerships in various spheres of business, then for intensification cooperation between companies and research and development institutions, in order to promote innovation and technological development as well as to the realization of joint projects in the field of technological improvements, product development, specialization, joint production and marketing. In addition to the company, an important role in the functioning of the cluster have different institutions, especially universities and colleges, local banks and laboratories for testing and certification. The course of development of clusters is significantly determined by the activities primarily the Ministry of Economy, and Commerce and Industry of Slovenia, IR center and 
other relevant ministries involved in numerous projects and activities in order to create conditions for the growth of clusters. The area that according to the research needs to be improved is the prevalence of low trust between large and small companies.

The geographical position, cheap labor, sewing skills among the female population were key reasons for the development of garment cluster in Galicia (Spain) (Bozdemir et al, 2009, p.19). In the frame of garment cluster in Galicia are some of the most famous brands of clothes (Zara and Massimo Dutti). Clothing cluster is characterized by a vertical core and non-vertically integrated manufacturers, designers and retailers, outsourcing machinery, raw materials and production complex logistics system which enables the transport of finished products, semi-finished products and raw materials, a number of banks and educational institutions to provide support services cluster and a system of institutions for the promotion of cooperation between members of the cluster. Thanks to the production specialization and vertical integration along the supply chain, Clothing Cluster Galicia today is the largest exporter of clothing Spain, which in total exports represent 48\% (Bozdemir, et al, 2009, p.11). An important feature of garment cluster of Galicia refers to the trend of dislocation, i.e. the migration tool production to countries with cheap labor, primarily in China and Africa. As already pointed out thanks to its geographical position, Galicia has managed to build a complex logistics system. Close to port facilitates the use of maritime transport, particularly significant for the receipt of goods produced in China. The clothing cluster of Galicia, also, there are several companies that provide supportive services. What needs to be emphasized as an important advantage of this cluster and easy access to a market of clothing Spain, which is not negligible. One drawback of this cluster should be noted that there is insufficient cooperation between the parties, then the potential danger of mass outsourcing a productive activity, lower productivity trade work in Galicia, fragmentation manufacturers, and low effectiveness of institutional support. Thus, the institutional support of the Galician Government cluster development mainly focused on campaigns and programs. Galician Clothing cluster is formed and evolved spontaneously So, thanks to the private sector in small Galician towns, i.e. companies which are able to recognize the necessity and benefits of connectivity, cooperation and joint appearance, and not as a result of the initiative of the local government.

\section{Business environment and cluster development in Serbia}

In Serbia, there are clusters of several years, however, there is no explicitly defined policies cluster. Clusters are still mentioned and they are objective, either directly or indirectly, in several national policy document above all as outlined in the Strategy of development of competitive and innovative small and medium-sized enterprises for the period 2008-2013. ("Off. Gazette of RS") and the draft strategy for the development of entrepreneurship and competitiveness for the period from 2014 to 2020 (www.privreda. gov. rs). Serbia has so far established over 50 clusters and a number of them located beside the other (higher) stage of development, while a few cluster initiatives can say that the zero phase of development. Among the most successful clusters of Serbia are: Automotive Cluster Serbia, ICT Network, Vojvodina ICT Cluster, Cluster fashion and clothing industry Serbia, Vojvodina Metal Cluster and Nis cluster of advanced technologies (www.ict-net.com/klasteri-srbije-udruživanje-kao ključ -uspeha-2). Apart from them, a group of clusters of the second phase (more) include, for example, and: Construction Cluster-Dunđer from Nis, and the Association for the promotion of competitiveness of agricultural machinery cluster BIPOM, In the group of clusters 
belonging to the so-called zero phase are: Cluster Association Renewable Energy and energy efficiency, Cluster Serbian Apothecary society, Association of manufacturers of herbal raw materials and herbal products HerbalPharmaNet (narr.gov.rs).

Clusters in Serbia do not have sufficient critical mass and their significance is still small, both nationally and internationally. According to general indicators are far from those in the EU, particularly in terms of employment, annual turnover and exports. Clusters of Serbia, for example, in 2013 gathered over 400 companies, employing just over 22,000 workers and had a turnover of around one billion euros annually-half of which relates to export (Vojvodina ictcluster.org/sr/clasteri-Srbije-potpisuju-memorandum-o-strateskojsaradnji /. For a comparative list of the competitiveness of the economy, in "'the Global Competitiveness Report 2014-2015" from 2014, covering 144 countries, Serbia is at the level of cluster development in ranked 115 th place. When you take into account that by the quality of local suppliers occupies the 98th position, quantity of local suppliers also the 110th place, and that is by cooperation between universities and industry in research and development on the 95th (World | Economic Forum, 2014, p. 329), then the answer to such a bad position when it comes to the level of development of clusters can be found primarily on two key factors: due to the insufficient level of perception management of local companies about the benefits that can be given to companies from the "cluster" of association and insufficient commitment and focus of government policy on cluster development.

Privacy cluster that has so far been applied in Serbia is insufficiently focused on the development of clusters, since cooperation in the process of research and development was very weak. Cooperation between companies within the cluster is mainly directed towards the attempt to internationalize rather than innovation and the creation of added value. Domestic clusters do not have or do not have adequate mechanisms of technological mediation and commercialization of scientific and technological research, such as technology centers and centers for the evaluation of the results of research and development, and cluster management is not able and willing to develop these skills.

Financial support clusters Government of the Republic of Serbia conducted by the competent Ministry of Economy and Regional Development through annual program to support cluster development. The programs are primarily aimed at citizens' associations, foundations or corporations that operate on the principle of the cluster. In order the program received funding, cluster must have at least 12 members, of which nine companies and three supporting institutions ( R \& D institutions, educational or other institution). Funds are allocated to clusters irrevocably refund up to $50 \%$ of completed projects. So for five years (2010-2014) approved 69 million dinars for the 61 cluster (www.napr.gov.rs). Cluster Development Program have supported or supported by some international development agencies and organizations (narr.gov.rs.index.php/projekti).

Further incentives for the formation of clusters in Serbia should be directed at those locations or product groups in which they identified the potential benefits in terms of efficiency (lower cost, including transaction), flexibility (e.g. Labor mobility) and innovation (diffusion of knowledge and cooperation). In line with this recommendation, it is necessary to reorganize the existing Program Cluster Development of the Government of the Republic of Serbia in a way that not only relate to the development of cluster initiatives, but also the development of clusters as geographic concentrations of companies from the sector. For example, the formation of Serbian garment cluster with a focus on production, would enable the joint appearance of domestic textile manufacturers in the markets of the EU and the Russian Federation, and, consequently, higher capacity utilization. Also, the arrival of Fiat can affect the intensive development of Serbian automotive cluster, which should lead to the creation of new jobs, to increase profit automotive industry and 
income of all participants in the production chain, to the successful export of Serbian products, deficit reduction and macroeconomic stability properties of the country. Potential entry of Ikea on the Serbian market could affect the formation of clusters in the Serbian furniture industry, in which a network of local producers and suppliers to operate at satisfying the needs of Ikea system, of course, assuming that instead of just opening a trade center, a Swedish company to achieve production cooperation with a local company (e.g. with Simpo or other furniture manufacturer) and a set of small and medium-sized suppliers. By establishing partnerships for example with Simpo, as well as assuming the role of a generator Serbian furniture cluster Ikea to Serbia has managed to secure what makes all these years distinctive, high quality and at a price affordable products, thanks to cheap labor and in our market. In addition, the arrival of Ikea in the Serbian market and better quality cooperation and mutual integration of the participants in the supply chain, raised to the level of their export and business opportunities, would provide the basis for the introduction of more sophisticated equipment and technology experience, as well as requirements for higher capacity utilization, increase productivity and competitiveness. Of course, if some other industries and other economic activities for the Serbian found a business partner with whom to connect local companies that would no doubt have multiple effects on our economy as a whole.

\section{Conclusion}

In Serbia, the clusters are not well developed, and is one of the goals of this work to promote their importance and necessity for the recovery of the Serbian economy and development. In overcoming the difficulties that arise in the process of building a cluster, the important role the state should play a leading economic factors involved in their creation and business (chambers of commerce, agencies and associations, as well as NGOs).

In order to create a more favorable environment for the development of clusters and strengthen existing cluster initiatives, it is necessary to implement the following policies: 1) Identify a clear long-term goals and strategies. 2) Enhance collaboration between the public and private sectors. 3) Strengthen cooperation with academic and research institution . 4) Strengthen support for clusters and provide a variety of funding sources. 5) Policy clusters align with other policies, so that it can provide a comprehensive and coordinated support to clusters. 6) work out a national network of clusters that would gather all the clusters and facilitate the exchange of experiences and practices, management skills development and implementation of targeted training and capacity building. Also, international networking should be one of the tasks of the network. 7) The new clusters should arise from the process of bottom-up (bottom-up), motivated by the objective of creating an efficient value added and creating sustainable creation of clusters, and not induced by short-term financial incentives. 8) Encourage cluster initiatives in underdeveloped regions to balanced regional development.

The fulfillment of these policy measures for the growth of clusters would contribute to improving the competitive position of Serbia, especially with a large number of SMEs as key generators of entrepreneurship and innovation potential and significant subcontractors in networking activities involved in attracting investment, which would start the whole economy. Generally, entry into systems of multinational giants would increase the degree of capacity utilization of local SMEs, as well as their productivity, competitiveness, trade and export performance. 


\section{References}

Andreozi, B. (2005). Manual on the development of clusters: Employment Promotion Project. Belgrade, Ministry of Labour, Employment and Social policy of Republic of Serbia.

Anderson, T., Schwag Serger, S., Sørvik, J. \& Hansson, EW (2004). The Cluster Policies White Book. Malmo, Ikeda-International Organization for Economy and Enterprise Development.

Borras, P., \& Tsagdis, D. (2008). Cluster Policies in Europe: firms, institutions, and governance, London, UK: Edward Elgar Publishing Limited.

Bozdemir, G. Oliva, CJ, Jerez, P., \& Tamayo, LE (2009). Microeconomics of Competitiveness, Apparel Cluster and Calicia (Spain)

Bošković, G., \& Konstantinović, I. (2011). Klasteri malih i srednjih preduzeća - ključ ekonomskog razvoja, Škola Biznisa, 4 (4), 58-63.

Katels, C. Lindqvist, G., \& Sölvell, O. (2003). The Cluster Initiative Greenbook. Stockholm, The Competitiveness Institute.

OECD. (2007). Competitive Regional Clusters: National Policy Approaches, OECD Reviews of Regional Innovation. Paris, OECD.

Porter, M. (2008). Clusters, Innovation and Competitiveness-New findings and implications for policy. Stockholm, European Cluster Policy.

Sölvell, O. (2008). Clusters-balancing evolutionary and constructive forces. Stockholm, Center for Strategy and Competitiveness.

“Official Gazette of RS", No. 55/05, 71/05-correction, 10/07 and 65/08. Belgrade.

The Gallup Organization. (2006). 2006 Inn barometer on cluster 's role in facilitating innovation in Europe: Analytical Report. Brussels, European Commission.

Vojvodina ictcluster.org/sr/clasteri-Srbije-potpisuju-memorandum-o-strateškoj-saradnji/ (01.02.2015.)

World | Economic Forum. (2014). Global Competitiveness Report 2014-2015, Geneva. www.privreda.gov.rs (01.02.2015).

www.ict-net.com/klasteri-srbije-udruživanje-kao-ključ-uspeha-2/ (01.02.2015)

www.napr.gov.rs (01.02.2015).

Proceedings of work. (2010). Nebojsa Savic and Goran Pitic (ed.), Where does the competitiveness of Serbia. Belgrade, FEFA 